\title{
Comparison of Analytical Techniques for Thermal Stability Analysis of $\beta$-Cyclodextrin for an Ebola Virus Infection Treatment
}

\author{
Mayte Murillo ${ }^{2}$ and Robert A. Lodder ${ }^{1,2}$
}

1. Department of Pharmaceutical Sciences, University of Kentucky, Lexington, KY, USA Email: Lodder @ g.uky.edu

2. Department of Chemistry, University of Kentucky, Lexington, KY, USA

ABSTRACT: Each New Drug Application filed with the Food and Drug Administration (FDA) must include the analytical procedures to ensure the identity, strength, quality, purity, and potency of a drug substance and drug product. The BSN389 drug product (being developed to treat Ebola virus infections) includes beta cyclodextrin. Evidence must be provided that the analytical procedures used in testing BSN389 meet proper standards of accuracy, sensitivity, specificity, and reproducibility and are suitable for their intended purpose. The Bootstrap Erroradjusted Single-Sample Technique (BEST) software was used to compare the quantitative and qualitative power of IR and ${ }^{1} \mathrm{H}$ NMR to differentiate new and partially decomposed samples of beta cyclodextrin, and the best assay will be incorporated into the thermal stability protocol for BCD.

\section{INTRODUCTION}

Beta cyclodextrin, known simply as $\beta$-cyclodextrin or $\beta C D$ or $\mathrm{BCD}$, is a non-reducing cyclic oligosaccharide consisting of seven $\alpha-1,4-$ linked D-(+)-glucopyranosyl units (Figure 1). The seven membered ring is produced by enzymatic conversion of starch. This drug has applications not only in pharmaceuticals but also in the food and environmental industry. Toxins can be removed when the ring ensnares specific molecules that are targeted for removal. BCD is also a food additive that acts as a stabilizer for

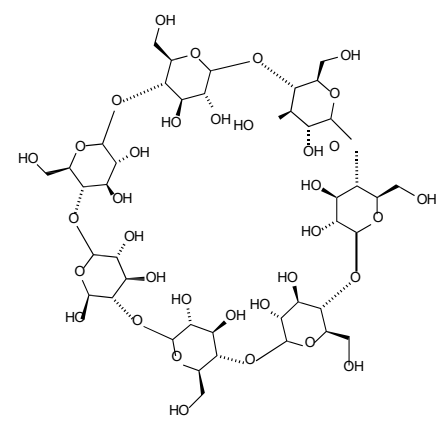

Figure 1. Structure of $\beta$-cyclodextrin.

flavors, colors, and some vitamins. ${ }^{2}$ BCD's estimated intake is about 1-1.4 g/day and it is approved by the FDA. Researchers are now taking known information about the cyclodextrin molecule and using it as a carrier for chemotherapeutic cytotoxic anticancer drugs. ${ }^{3}$

The analytical techniques ${ }^{1} \mathrm{H}$ NMR and infrared (IR) spectro-scopy are used to measure the difference between decomposed and stable versions of BCD in this research. The Bootstrap Erroradjusted Single- sample Technique (BEST) software (see Appendix) will then identify the best analytical method to use for the thermal stability regulatory procedure for the drug.

\section{METHODS}

\section{Preparation of Samples}

Approximately two grams of beta cyclodextrin was slightly decomposed thermally by putting the sample on a Pyrex dish and placing it in a conventional oven, heating it slowly to about $232{ }^{\circ} \mathrm{C}$ at a linear rate of about $28^{\circ} \mathrm{C} / 5 \mathrm{~min}$ until the white powder sample was a slightly yellow color.

\section{Measurements}

Six separate samples of the pure and decomposed BCDs were prepared with deuterated water. H NMR spectra were recorded on a $500 \mathrm{MHz}$ JOEL spectrometer, and processed with 16 scans ranging from -2 to $16 \mathrm{ppm}$. These samples were then also analyzed using a Thermo Scientific Nicolet iS10 infrared spectrometer over a wavenumber range of $4000-500 \mathrm{~cm}^{-1}$.

\section{Analysis}

The ${ }^{1} \mathrm{H}$ NMR data were entered in TopSpin and converted into CVS files. These data along with the IR values were read into MATLAB. Each sample set of data was linked together in a variable with dimensions equal to the number of wavenumbers or chemical shifts. Each set was plotted as described in Appendix 1. The BEST program was used to determine the distance in multidimensional standard deviations (SDs) between the set of samples of pure and decomposed BCD. These values were then compared to the control distances, which were found by finding the distances between the center of the pure BCD validation spectra each pure $\mathrm{BCD}$ validation spectrum.

\section{RESULTS AND DISCUSSION}

\section{Characterization of $B C D$}

As shown in Figure 2 and 3, the structure of BCD was characterized by ${ }^{1} \mathrm{H}-\mathrm{NMR}$ and IR spectroscopy. Figure 2 shows the ${ }^{1} \mathrm{H}-\mathrm{NMR}$ spectrum of decomposed and pure BCD. Results showed only slight left shift of the decomposed sample. Figure 3 shows a comparison of the IR spectra between the pure and decomposed drug. The decomposed sample showed a slight blue shift in the $\mathrm{O}-\mathrm{H}$ stretch vibrations. 
bioRxiv preprint doi: https://doi.org/10.1101/448928; this version posted October 22, 2018. The copyright holder for this preprint (which was not certified by peer review) is the author/funder, who has granted bioRxiv a license to display the preprint in perpetuity. It is made available under aCC-BY 4.0 International license.

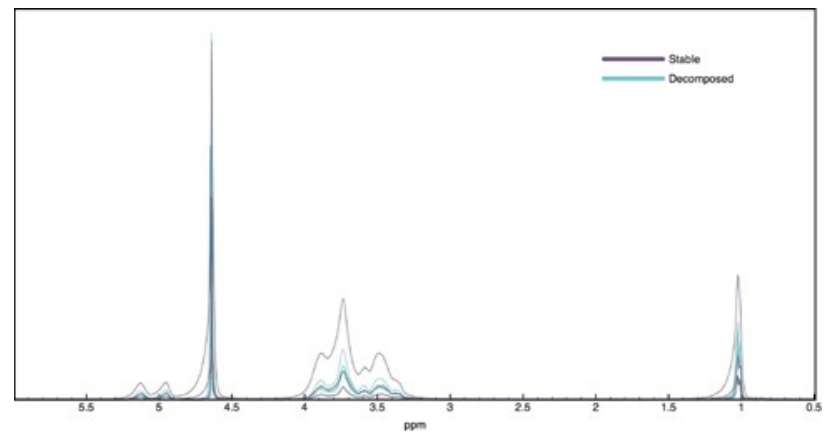

Figure 2. ${ }^{1} \mathrm{H}$ NMR for BCD

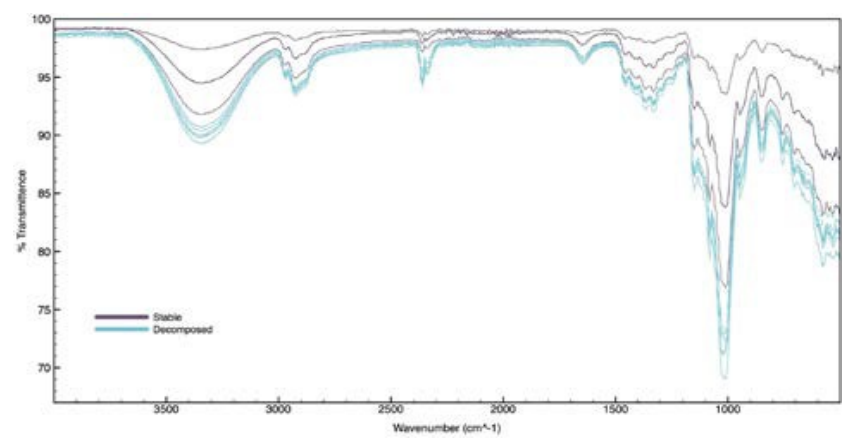

Figure 2. IR spectra of BCD

\section{Analysis of Techniques}

Table 1 shows the standard deviations output by the BEST software. The average values for the ${ }^{1} \mathrm{H}$ NMR were higher than the average values for the IR, 6.3100 and 4.9900 respectively. This showed the differences between the stable and decomposed sample that are not obvious when shown graphically (Figures 2 and 3). The controls were expected to be less than three. There were two outliers in the NMR spectra. The outliers will be checked by LCMS in a follow-up study.

\section{CONCLUSION}

Beta cyclodextrin samples were tested by IR and NMR. Tests showed small differences between the pure and slightly decomposed samples. The BEST software suggests that proton NMR is superior for thermal stability of BCD, but the variability is large and the outliers need to be investigated.
It is worth noting that the Mahalanobis distance between the IR and NMR samples could not be calculated because the number of rows of the data matrix must exceed the number of columns. The BEST software was able to overcome this obstacle and provide a useful result.

\section{ACKNOWLEDGEMENTS}

The project described was supported by the National Center for Research Resources and the National Center for Advancing Translational Sciences, National Institutes of Health, through Grant UL1TR001998, and by the National Science Foundation through NSF ACI-1053575 allocation number BIO170011. The content is solely the responsibility of the authors and does not necessarily represent the official views of the NIH.

\section{REFERENCES}

(1)Solutions, N. C. Parchem - fine \& specialty chemicals is a Leading Supplier of Enzymes such as Beta Cyclodextrin https://www.parchem.com/news-articles/Parchem-fine-specialty-

chemicals-is-a-Leading-Supplier-of-Enzymes-such-as-Beta-CyclodextrinN000192.aspx (accessed Dec 12, 2017).

(2) EFSA PanelonFoodAdditivesandNutrient Sourcesadded toFood (ANS); Mortensen, A.; Aguilar, F.; Crebelli, R.; Di Domenico, A.; Dusemund, B.; Frutos, M. J.; Galtier, P.; Gott, D.; Gundert-Remy, U.; Leblanc, J.; Lindtner, O.; Moldeus, P.; Mosesso, P.; Parent-Massin, D.; Oskarsson, A.; Stankovic, I.; Waalkens-Berendsen, I.; Woutersen, R. A.; Wright, M.; Younes, M.; Boon, P.; Chrysafidis, D.; Gürtler, R.; Tobback, P.; Arcella, D.; Rincon, A. M.; Lambré, C.EFSA Journal2016, 14 (12).

Table 1. BEST results comparing pure and decomposed samples.

\begin{tabular}{c|c|c|c|c}
\multirow{2}{*}{ Sample } & \multicolumn{2}{|c|}{ NMR } & \multicolumn{2}{c}{ IR } \\
\hline 1 & Pure/Decomposed & Pure/Pure & Pure/Decomposed & Pure/Pure \\
\hline 2 & 3.7103 & 1.8613 & 4.3276 & 1.2500 \\
3 & 1.6542 & 1.8611 & 4.8218 & 1.5973 \\
4 & 11.6069 & 1.6542 & 4.7514 & 1.7374 \\
5 & 10.6345 & 0.9857 & 5.0882 & 1.8101 \\
6 & 6.5937 & 2.1662 & 5.8849 & 1.3649 \\
\hline
\end{tabular}


bioRxiv preprint doi: https://doi.org/10.1101/448928; this version posted October 22, 2018. The copyright holder for this preprint (which was not certified by peer review) is the author/funder, who has granted bioRxiv a license to display the preprint in perpetuity. It is made available under aCC-BY 4.0 International license.

\section{APENDIX I}

\section{REPLICA PROGRAM}

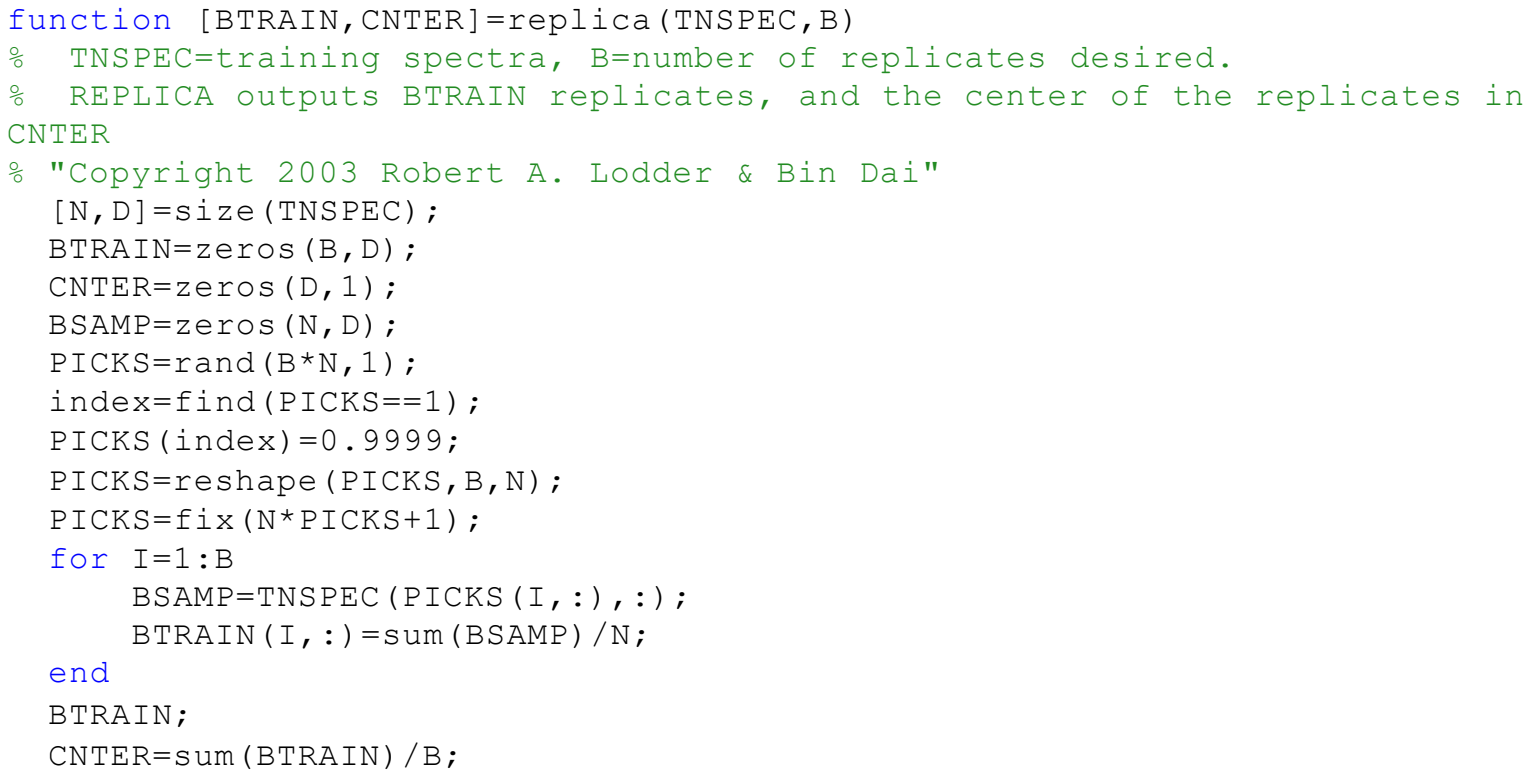

\section{QB PROGRAM}

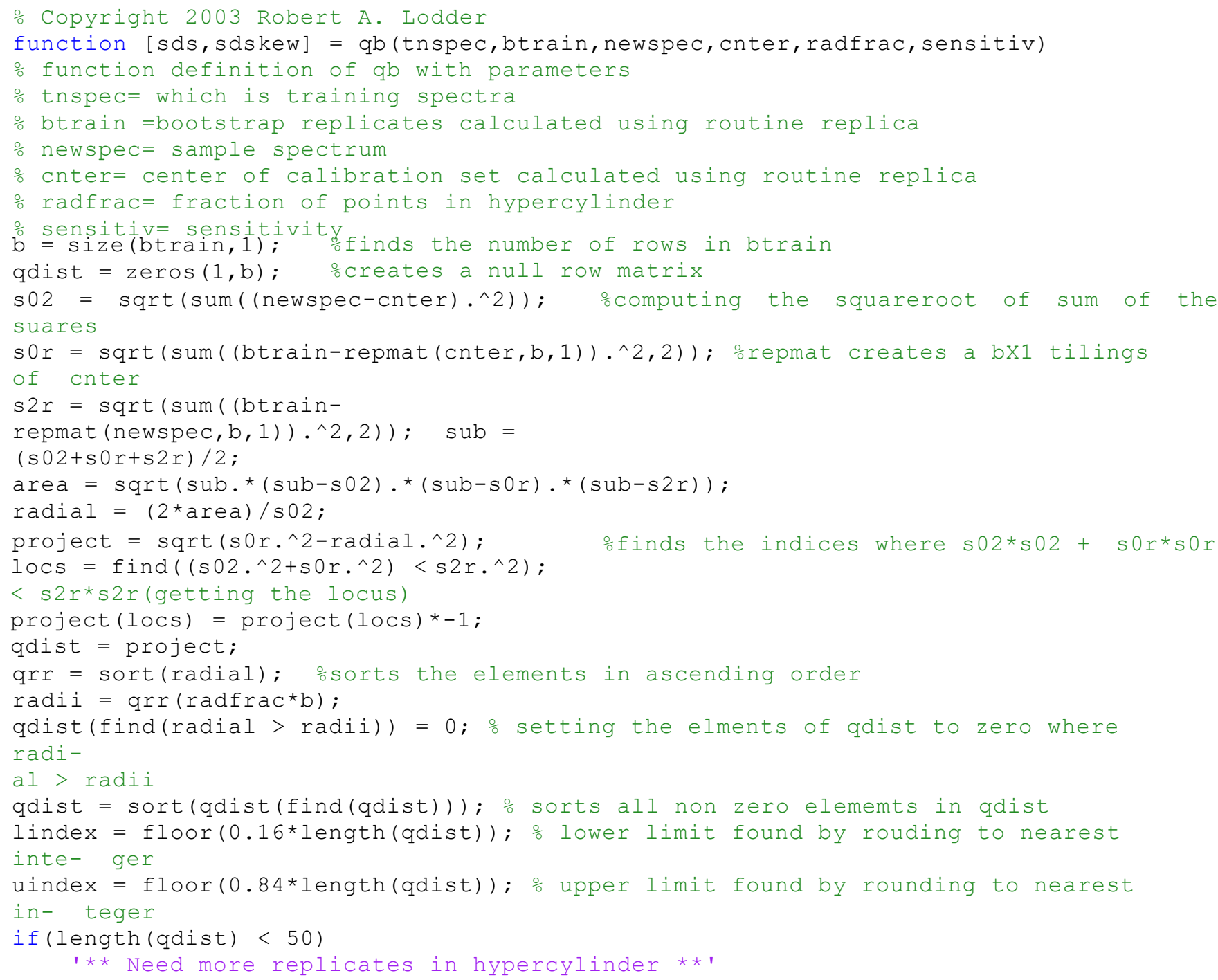


bioRxiv preprint doi: https://doi.org/10.1101/448928; this version posted October 22, 2018. The copyright holder for this preprint (which was not certified by peer review) is the author/funder, who has granted bioRxiv a license to display the preprint in perpetuity. It is made available under aCC-BY 4.0 International license.

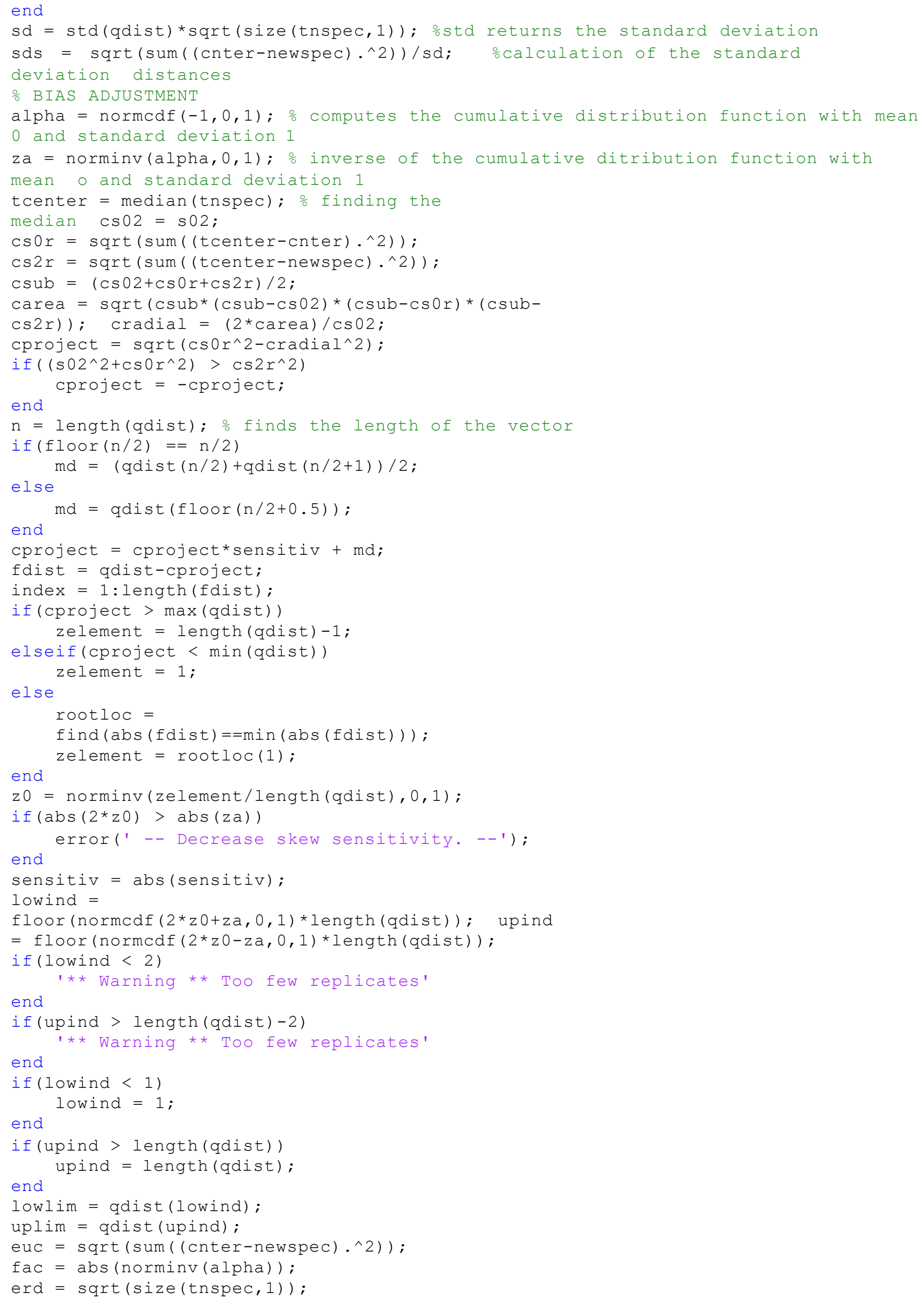


bioRxiv preprint doi: https://doi.org/10.1101/448928; this version posted October 22, 2018. The copyright holder for this preprint (which was not certified by peer review) is the author/funder, who has granted bioRxiv a license to display the preprint in perpetuity. It is made available under aCC-BY 4.0 International license.

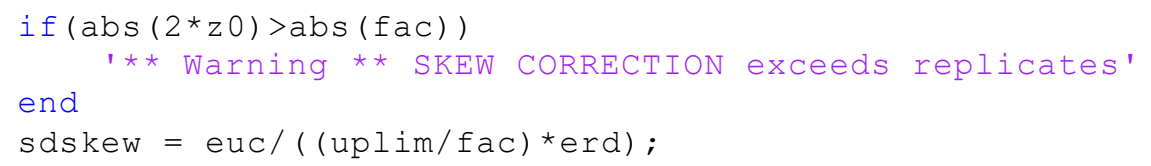

\section{NMR COMPARISON}

$>>$ NMR_stable $=$ zeros $(2,2)$;

NMR_decomposed=zeros $(2,2)$;

$>>$ ppm=zeros $(2,2)$;

$>$ plot(ppm,NMR_stable);

hold on

plot(ppm,NMR_decomposed);

hold off

[BTRAIN,CNTER] $=$ replica(NMR_stable,1000);

$[$ sds,sdskew $]=$ qb(NMR_stable,BTRAIN,NMR_decomposed(1,:),CNTER,0.25,0);

$>$ sds

$\operatorname{sds}=$

\subsection{3}

$>>[$ sds,sdskew $]=q b\left(N M R \_s t a b l e, B T R A I N, N M R \_d e c o m p o s e d(2,:), C N T E R, 0.25,0\right)$;

$>$ sds

$\operatorname{sds}=$

\subsection{2}

$>>[$ sds,sdskew $]=q b\left(N M R \_s t a b l e, B T R A I N, N M R \_d e c o m p o s e d(3,:), C N T E R, 0.25,0\right)$;

$>>$ sds

$\operatorname{sds}=$

\subsection{2}

$>>[$ sds,sdskew $]=q b\left(N M R \_s t a b l e, B T R A I N, N M R \_d e c o m p o s e d(4,:), C N T E R, 0.25,0\right)$;

$>$ sds

$\operatorname{sds}=$

\subsection{9}

$>>[$ sds,sdskew $]=q b\left(N M R \_s t a b l e, B T R A I N, N M R \_d e c o m p o s e d(5,:), C N T E R, 0.25,0\right)$; 
bioRxiv preprint doi: https://doi.org/10.1101/448928; this version posted October 22, 2018. The copyright holder for this preprint (which was not aCC-BY 4.0 International license.

$>$ sds

$\operatorname{sds}=$

10.6345

$>>[$ sds,sdskew $]=q b\left(N M R \_s t a b l e, B T R A I N, N M R \_d e c o m p o s e d(6,:), C N T E R, 0.25,0\right)$;

$>$ sds

$\operatorname{sds}=$

6.5937

$>>[$ sds,sdskew $]=q b\left(N M R \_s t a b l e, B T R A I N, N M R \_s t a b l e(1,:), C N T E R, 0.25,0\right) ;$

$>$ sds

$\operatorname{sds}=$

1.8613

$>>[$ sds,sdskew $]=q b\left(N M R \_s t a b l e, B T R A I N, N M R \_s t a b l e(2,:), C N T E R, 0.25,0\right) ;$

$>$ sds

$\operatorname{sds}=$

\subsection{1}

$>>$ sds,sdskew $]=q b\left(N M R \_s t a b l e, B T R A I N, N M R \_s t a b l e(3,:), C N T E R, 0.25,0\right) ;$

$>$ sds

$\operatorname{sds}=$

1.6542

$>>[$ sds,sdskew $]=q b\left(N M R \_s t a b l e, B T R A I N, N M R \_s t a b l e(4,:), C N T E R, 0.25,0\right) ;$

$>$ sds

$\operatorname{sds}=$

0.9857

$>>[$ sds,sdskew $]=q b\left(N M R \_s t a b l e, B T R A I N, N M R \_s t a b l e(5,:), C N T E R, 0.25,0\right) ;$

$>$ sds

$\operatorname{sds}=$

\subsection{2}

$>>[$ sds,sdskew $]=q b\left(N M R \_s t a b l e, B T R A I N, N M R \_s t a b l e(6,:), C N T E R, 0.25,0\right) ;$ 
bioRxiv preprint doi: https://doi.org/10.1101/448928; this version posted October 22, 2018. The copyright holder for this preprint (which was not certified by peer review) is the author/funder, who has granted bioRxiv a license to display the preprint in perpetuity. It is made available under aCC-BY 4.0 International license.

$>$ sds

$\operatorname{sds}=$

\subsection{5}

\section{IR COMPARISON}

$>>$ IR_stable=zeros(2,2);

IR_decomposed=zeros(2,2);

wavenumber=zeros $(2,2)$;

>> plot(wavenumber,IR_stable);

hold on

plot(wavenumber,IR_decomposed);

hold off

[BTRAIN,CNTER]=replica(IR_stable,1000);

$>>[$ sds,sdskew $]=$ qb(IR_stable,BTRAIN,IR_decomposed(1,:),CNTER,0.25,0);

$>$ sds

$\operatorname{sds}=$

4.3276

$>>$ sds,sdskew $]=$ qb(IR_stable,BTRAIN,IR_decomposed(2,:),CNTER,0.25,0);

$>$ sds

$\operatorname{sds}=$

4.8218

$>>[$ sds,sdskew $]=q b\left(I R \_s t a b l e, B T R A I N, I R \_d e c o m p o s e d(3,:), C N T E R, 0.25,0\right)$;

$>$ sds

$\operatorname{sds}=$

\subsection{4}

$>>$ sds,sdskew $]=$ qb(IR_stable,BTRAIN,IR_decomposed(4,:),CNTER,0.25,0);

$>$ sds

$\operatorname{sds}=$

\subsection{2}

$>>$ sds,sdskew $]=q b\left(I R \_s t a b l e, B T R A I N, I R \_d e c o m p o s e d(5,:), C N T E R, 0.25,0\right)$; 
bioRxiv preprint doi: https://doi.org/10.1101/448928; this version posted October 22, 2018. The copyright holder for this preprint (which was not certified by peer review) is the author/funder, who has granted bioRxiv a license to display the preprint in perpetuity. It is made available under aCC-BY 4.0 International license.

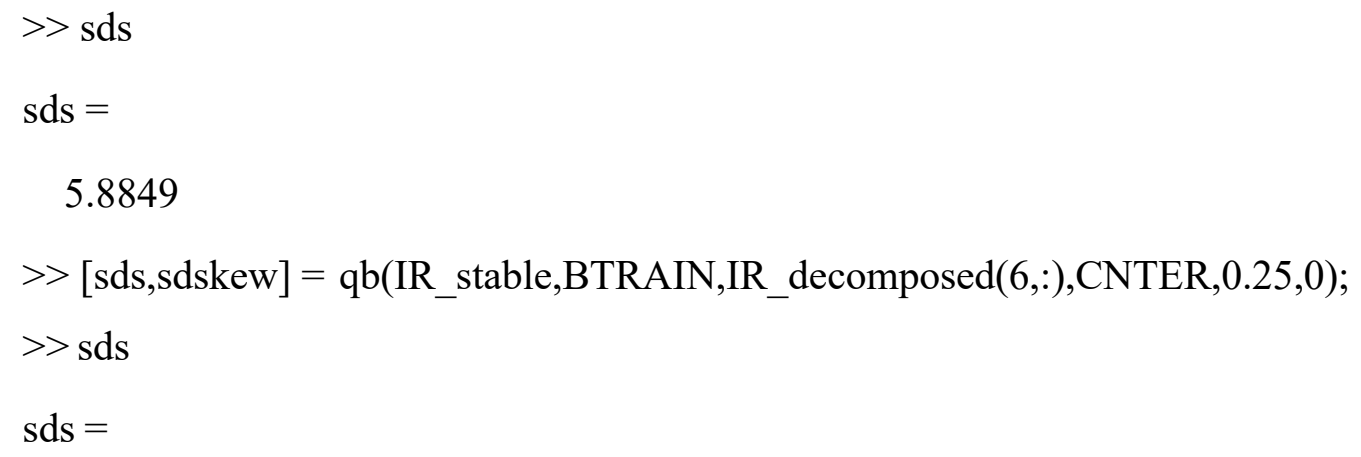


bioRxiv preprint doi: https://doi.org/10.1101/448928; this version posted October 22, 2018. The copyright holder for this preprint (which was not certified by peer review) is the author/funder, who has granted bioRxiv a license to display the preprint in perpetuity. It is made available under

Error using mahal (line 38)

The number of rows of $\mathrm{X}$ must exceed the number of columns. 